\title{
A Patient with Short Stature with Normal Growth Hormone Provocative Tests and Low Physiological 24 hr Growth Hormone Concentration
}

\author{
Yukihiro Hasegawa, Tomonobu Hasegawa, Shinobu Kotoh and Yutaka Tsuchiya \\ Division of Pediatric Endocrinology and Metabolism, \\ Tokyo Metropolitan Kiyose Children's Hospital, Tokyo, Japan
}

\begin{abstract}
We report a patient with short stature with normal GH provocative tests and low physiological 24 hour GH concentration. After starting GH treatment, growth velocity increased similarly to that seen in patients with a severe type of growth hormone deficiency. This is the first precise case report of a patient with typical neurosecretory dysfunction without any other complications.
\end{abstract}

Key words: growth hormone neurosecretory dysfunction, GH provocative tests, $24 \mathrm{hr}$ mean GH concentration

\section{Introduction}

Traditionally, the diagnosis of growth hormone deficiency (GHD) has been made from the results of $\mathrm{GH}$ provocative tests and $\mathrm{GH}$ treatment was given only to patients with GHD [1]. After the development of recombinant technology, GH therapy has been given to quite a number of patients other than GHD such as Turner syndrome $[2,3]$ and so-called normal short children [4-8]. Among normal short children who have been conventionally defined by the results of $\mathrm{GH}$ provocative tests, the concept of GH neurosecretory dysfunction

Received: December 17, 1992

Accepted: April 9, 1993

Correspondence: Dr. Yukihiro Hasegawa, Division of Pediatric Endocrinology and Metabolism, Tokyo Metropolitan Kiyose Children's Hospital 1-3-1, Umezono, Kiyose, Tokyo 204 Japan
(NSD) was proposed [9] and it was reported that GH therapy would increase the height of patients with NSD at least in a short range of the treatment years [10-13].

Originally, patients with NSD have short stature with delayed bone age, normal results of GH provocative tests, a low level of insulinlike growth factor-1 (IGF-1) and a low mean level of physiological $24 \mathrm{hr}$ GH concentrations [9]. Since the concept was published, 24 hour or 12 hour overnight measurements of $\mathrm{GH}$ concentration (24-M-GH, N-M-GH, respectively) have been reported to be useful in analysing who should be treated among short children [10-14].

It remains to be clarified whether NSD is commonly seen in patients with short stature, although there are some reports where spontaneous $\mathrm{GH}$ secretion is low in patients with Turner syndrome [15], and brain tumor with irradiation [16]. As far as we know, there 
has been no single, precise case report of NSD, although there have been several reports about the data of NSD as a group [9-13].

Here we present a patient with normal $\mathrm{GH}$ provocation tests and low mean levels of 24-M-GH. Height gain after GH treatment was obtained similarly to that in a severe type of GHD.

\section{Methods}

All the GH levels were measured by a commercially available GH IRMA kit (Eiken, Tokyo, Japan). Serum IGF-1 and IGF binding protein-3 (IGFBP-3) levels were measured by previously reported methods [17-20].

Arginine and insulin tests were done as previously described [21].

Mean levels of 24-M-GH were calculated based upon the $\mathrm{GH}$ levels every 30 minutes as previously described [22]. Mean levels of N-M-GH were calculated based upon the GH levels every 30 minutes from 8 p.m. to $7: 30$ a.m.

\section{Case Report}

This Japanese girl was first seen in our clinic because she was short (mean-6.5 SD for Japanese girl standard [23]) at the age of three years and nine months. She was born as one of twins, by spontaneous vaginal, breech delivery at 35 weeks' gestation. Her Apgar score was nine at five minutes. She measured $45 \mathrm{~cm}$ and weighed $2.10 \mathrm{~kg}$ at birth. Her father and mother were $170 \mathrm{~cm}$ and $160 \mathrm{~cm}$ tall, respectively.

At the age of three years and four months at the regular health check at a local health center, she was referred to a local hospital because of short stature. At this hospital, her $\mathrm{GH}$ peak of insulin tolerance test was $16 \mathrm{ng} / \mathrm{ml}$ (Table 1).

At the age of three years and nine months, she was referred to our hospital. Her growth chart was as in Figure 1. Physical examination
Table 1. IGF- I, IGFBP-3, GH peaks during arginine (Arg.) and insulin (Ins.) tests, and physiological GH mean concentration. Physiological GH mean concentration was measured for a whole day and overnight (24-M-GH and N-M-GH, respectively. See in Methods). Normal mean levels of 24-M-GH and N-M-GH (mean \pm SD, range, $n=21$ ) are $4.4 \pm 1.2,2.2-6.7$ and $5.4 \pm$ $2.1,2.4-10.0 \mathrm{ng} / \mathrm{ml}$, respectively.

\begin{tabular}{ccccccc}
\hline CA & $\begin{array}{c}\text { IGF-1 } \\
\text { IGFBP-3 }\end{array}$ & $\begin{array}{c}\text { GH peak } \\
\text { Arg. Ins. } \\
\text { (ng/ml) }\end{array}$ & $\begin{array}{c}\text { 24-M-GH } \\
\text { (ng/ml) } / \mathrm{ml} \text {-GH }\end{array}$ & (ng/ml) \\
\hline $3: 04$ & & & & 16.0 & & \\
$3: 09$ & & & 14.4 & 13.5 & 0.82 & 1.17 \\
$3: 11$ & & 0.80 & 8.0 & 28.5 & 0.81 & 1.23 \\
& & & & & & 0.55 \\
$5: 02$ & 47.1 & 0.51 & & 25.1 & & 1.42 \\
& 49.3 & 0.60 & & & & \\
\hline
\end{tabular}

CA: chronological age, 3:04 means three years and four months.

was unremarkable. Her bone age was one year and six months (Greulich and Pyle method). On the magnetic resonance image, mild atrophy of the anterior pituitary gland was noted. Neither transection of the pituitary stalk nor ectopic posterior lobe was detected. We did arginine and insulin tests four times (at the age of three years and nine months, and three years and 11 months) and did 24-M-GH or N-M-GH three times, with parental consent (Table 1). Three out of four GH provocative tests showed $\mathrm{GH}$ peaks over $10 \mathrm{ng} / \mathrm{ml}$. All mean levels of 24-M-GH and N-M-GH were extremely low, compared with our normal values [22]. Our normal mean levels of 24-M$\mathrm{GH}$ and N-H-GH during the prepubertal period (mean $\pm \mathrm{SD}$ ) were $4.4 \pm 1.2$ (range 2.2$6.7, \mathrm{n}=21$ ), $5.4 \pm 2.1$ (range 2.4-10.0, $\mathrm{n}=21$ ) ng/ $\mathrm{ml}$, respectively (22, our unpublished results).

The results of serum IGF-I and IGFBP-3 levels are also shown in Table 1. Those IGF. I and IGFBP-3 values were lower than the lower limit of age-matched controls [17-20].

At the age of three years and 11 months, we started $\mathrm{GH}$ therapy $(0.5 \mathrm{U} / \mathrm{kg} /$ week, six times a week). Height velocity SD score [23] improved from -8.6 (pretreatment) to +1.9 (one year after $\mathrm{GH}$ treatment). Delta height increment (subtracting pretreatment height velocity $(\mathrm{cm} /$ year) from post-treatment height 
GH Neurosecretory Dysfunction?

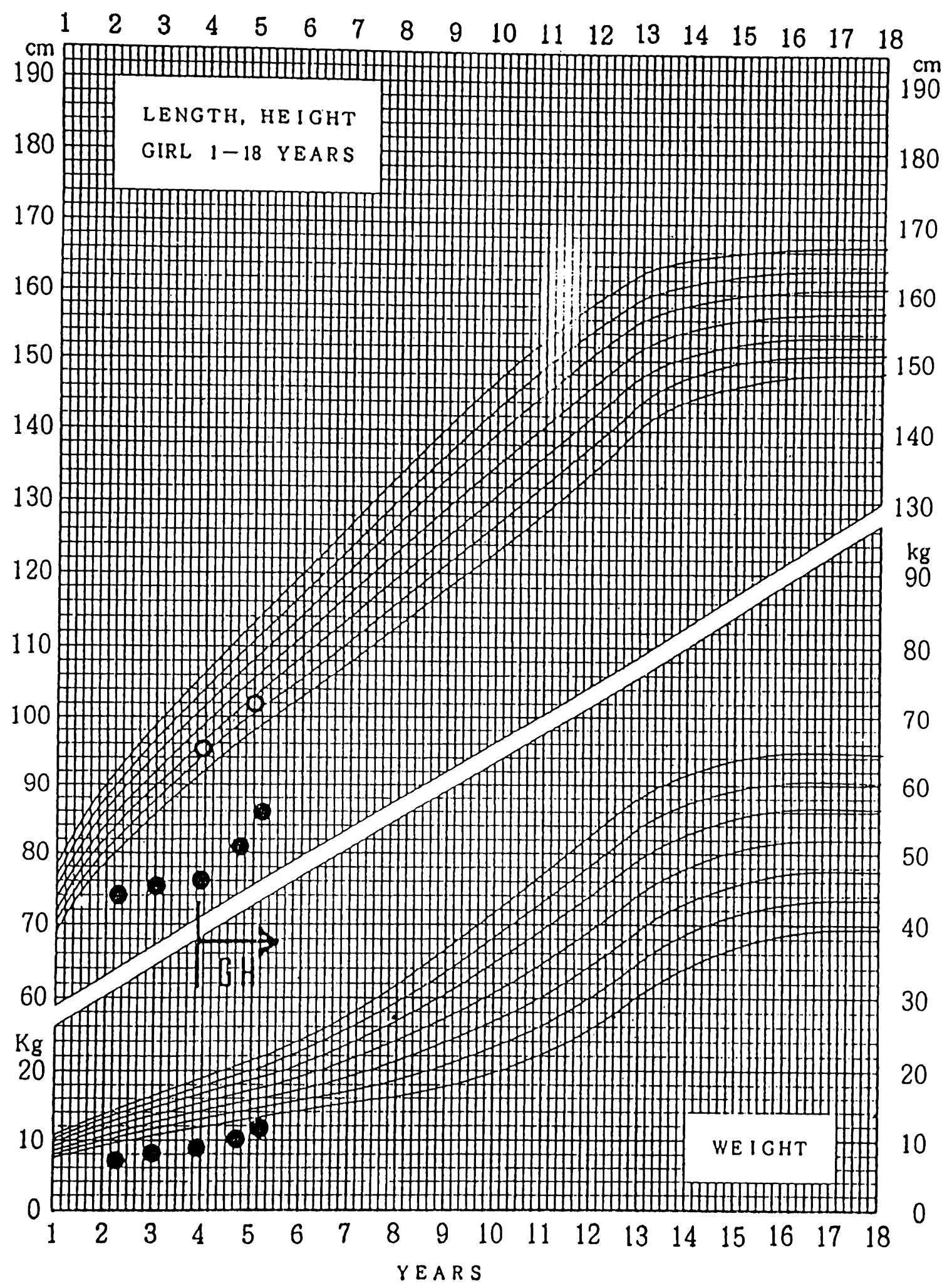

Fig 1. Growth curve of this patient and her sister on cross-sectional percentile growth curve for Japanese girls [33]. Closed and open circle indicate height of her and her sister (twins). The seven lines show 3rd, 10th, 25th, 50th, 75th, 90th, and 97th percentile. 
velocity $(\mathrm{cm} /$ year)) was $7.9 \mathrm{~cm}$, one year after starting GH therapy. This delta height increment is quite similar to that of a severe type of prepubertal GHD with the same style of GH treatment in our hospital $(n=14$, mean $\pm S D$; $7.6 \pm 2.1 \mathrm{~cm}$ ).

At the age of five years and one month, we stopped $\mathrm{GH}$ treatment for two weeks and reevaluated $\mathrm{GH}$ secretion capacity, with parental consent (Table 1). We obtained similar results of the $\mathrm{GH}$ provocation test and low physiological GH levels as before.

\section{Discussion}

Five out of six GH provocation tests (insulin, arginine) showed $\mathrm{GH}$ peaks over $10 \mathrm{ng} / \mathrm{ml}$. The result of the arginine test at the age of three years and 11 months was considered to be false positive if we arbitrarily decide the cutoff line of $\mathrm{GH}$ provocation tests is $10 \mathrm{ng} / \mathrm{ml}$, because the other results of $\mathrm{GH}$ provocation tests were completely normal. It has been reported that some apparently normal short children, who were defined by the other GH provocation tests, showed false positive results [24-26]. According to our data, the false positive rate in normal short children was $23 \%$ [21].

The results in our case, namely, normal results of $\mathrm{GH}$ stimulation tests, low IGF-I, and low mean levels of $24-\mathrm{M}-\mathrm{GH}$ were compatible with the original concept of NSD. The therapeutic success in our case was also consistent with the original concept of NSD.

Although some reports have been in favour of the concept of NSD [9-13], some have been against the concept $[27-29]$. One issue against the concept is that $24-\mathrm{M}-\mathrm{GH}$ or N-M-GH do not give us reproducible results [27-28]. The other issue against the concept is that normal values of mean level of $24-\mathrm{M}$ $\mathrm{GH}$ overlap with those of patients with GHD [29]. The definition of NSD is not yet clearly made among researchers.

This case report suggests that a case clearly exists which has normal $\mathrm{GH}$ provocation tests and a low mean level of 24-M-GH, with growth on $\mathrm{GH}$ therapy, quite similarly to a classical GHD. We think that it is important to make a diagnosis carefully after repeating $\mathrm{GH}$ provocation tests and measurements of $\mathrm{GH}$ during 12 or $24 \mathrm{hr}$, because there are some limitations of $\mathrm{GH}$ provocative tests such as reproducibility [30-32] and false positive tests [23-26] as well as those of 12 or 24 hour measurements of $\mathrm{GH}$ as described above.

Finally, of note is that this kind of condition, a case with "typical" NSD, is probably very rare, because in our seven years' experience (150 short children, and about 50 24-M$\mathrm{GH}$ analyses), this is the only case with low IGF- I levels, normal GH provocation tests and low mean levels of 24-M-GH. We think that further study of neurosecretory dysfunction, especially how to define the concept, is needed.

\section{References}

1. Underwood LE, Van Wyk JJ. Normal and aberrant growth. In: Wilson JD, Foster DW, editors. Williams Textbook of Endocrinology, Tokyo: WB Saunders Company, 1992: 1079-138.

2. Nilsson KO. What is the value of growth hormone treatment in short children with special syndrome? Acta Paediatr Scand Suppl 1989; 362: 61-8.

3. Rosenfeld RG, Hinz RL, Johanson AJ, Sherman B, Brasel JA, Burstein S, et al. Three year results of a randomized prospective trial of methionyl human growth hormone and oxandrolone in Turner syndrome. J Pediatr 1988; 113: 393-400.

4. Van Vliet G, Styne DM, Kaplan SL, Grumback MM. Growth hormone treatment for short stature. N Engl J Med 1983; 309: 1016-22.

5. Ivarsson SA. Can growth hormone increase final height in constitutional short stature? Acta Pediatr Scand 1989; 362 (Suppl): 56-60.

6. Gerner JM, Genel M, Gianfredi SP, Hintz 
GH Neurosecretory Dysfunction?

RL, Rosenfeld RG, Tamborlane WV, et al Prospective clinical trial of human growth hormone in short children without growth hormone deficiency. J Pediatr 1984; 104: 172-6.

7. Ad Hoc Committee on Growth Hormone Usage, The Lawson Wilkins Pediatric Endocrine Society (Underwood LE, Chairman). Growth hormone in the treatment of children with short stature. Pediatrics 1983; 72: 891-4.

8. Grunt J, Howard C, Daughaday W. Comparison of growth and somatomedin $\mathrm{C}$ responses following growth hormone treatment in children with small-for-date short stature, significant idiopathic short stature and hypopituitarism. Acta Endocrinol 1984; 106: 168-74.

9. Spiliotis BE, August GP, Hung W, Sonis W, Mendelson W, Bercu BB. Growth hormone neurosecretory dysfunction: A treatable cause of short stature. JAMA 1984; 251: 2223-30.

10. Hernadez M, Nieto JA, Sobradillo B, Pombo M, Ferandez A, Rejas J. Multicenter clinical trial to evaluate the therapeutic use of recombinant growth hormone from mammalian cells in the treatment of growth hormone neurosecretory dysfunction. Horm Res 1991; 35: 13-8.

11. Chelw SA, Raiti S, Amour KM, et al. Therapy in short children with subnormal integrated concentrations of growth hormone. Am J Dis Child 1987; 14: 1195-8.

12. Kowarski A, Zadik Z, Hoff J, and Multicenter Collaborative study group. Similar response to somatropin therapy in classical growth hormone (GH) deficiency and neurosecretory $\mathrm{GH}$ dysfunction (Abstract). Hormone Res 1989; 31 (suppl 1): 38 .

13. Bercu BB, Diamond FB Jr. Growth hormone neurosecretory dysfunction. Clin Endocrinol Metab 1986; 15: 537-90.

14. Saggese G, Cesaretti G, Cinquanta L, Giannessi N, Bracaloni C, Di Spigno G, et al. Evaluation of 24-hour growth hormone spontaneous secretion: comparison with a nocturnal and diurnal 12-hour study. Horm Res 1991; 35: 25-9.

15. Albertsson-Wikland K, Rosberg S. Pattern of spontaneous growth hormone secretion in Turner syndrome. In: Ranke MB, Rosenfeld R, editors. Turner's syndrome and growth-promoting therapies. Amsterdam: Excerpta Medica, 1991: 23-8.

16. Shalet SM. Irradiation-induced growth failure. In: Savage MO, Randall RA, editors. Clinics in endocrinology and metabolism (growth disorders). London: WB Saunders Company, 1986: 591-606.

17. Hasegawa Y, Hasegawa T, Yokoyama T, Kotoh S, Tsuchiya Y, Nose O, et al. Usefulness of IGF. I measurement (after acid extraction) for diagnosis of growth hormone deficiency. Horumon-to-Rinsyo 1992; 40(10): 1107-10 (in Japanese).

18. Hasegawa Y, Hasegawa T, Yokoyama T, Kotoh S, Tsuchiya Y, Nose O, et al. Usefulness and limitation of measurement of IGFBP-3 for diagnosis of growth hormone deficiency. Endocrinol Japon 1992; 39: 58591.

19. Hasegawa Y. The clinical utility of IGFBP. 3 measurements in the diagnosis of growth hormone deficiency. Clinical Pediatric Endocrinology (1993, in print).

20. Toyama M, Kurimoto $F$, Hasegawa $Y$, Hasegawa T, Tsuchiya Y. Methodology of IGFBP-3 RIA. Horumon-to-Rinsyo 1992; 40(10): 1085-90 (in Japanese).

21. Hasegawa Y, Hasegawa T, Kotoh S, Tsuchiya Y. False positive ratios of GH provocation tests (arginine and insulin) in control and normal short children. Clinical Pediatric Endocrinology (1993, in print).

22. Hasegawa T, Hasegawa Y, Yokoyama T, Kotoh S, Tsuchiya, Y. Spontaneous Growth Hormone Secretion in Healthy Prepubertal Children of Normal Stature. Endcrinol Japon 39(1); 9:12, 1992.

23. Suwa S, Tachibana K, Maesaka H, Tanaka T, Yokoya S. Longitudinal Standards for height and height velocity for Japanese children from birth to maturity. Clin 
Pediatr Endocrinol 1(1); 5-13, 1992.

24. Frasier SD. A review of growth hormone stimulation tests in children. Pediatrics 1974: 53; 929-37.

25. Kaplan SL, Abrams CAL, Bell JJ, Conte FA, Grumbach MM. Growth and growth hormone: Changes in serum level of growth hormone following hypoglycemia in disorders of growth. Pediat. Res., 1968: 2: 43.

26. Root AW, Saenz-Rodriguez C, Bongiovanni AM, Everlein WR. The effect of arginine infusion on plasma growth hormone and insulin in children. J Pediat 1969: 74; 187.

27. Lanes R. Diagnostic limitations of spontaneous growth hormone measurements in normally growing prepubertal children. Am J Dis Child 1989; 143: 1284-6.

28. Kerrigan JR, Martha PM Jr, Blizzad RM, Christie CM, Rogol AD. Variations of pulsatile growth hormone release in healthy short prepubertal boys. Pediatr Res 1990; 28: $11-4$.

29. Rose SR, Ross JL, Uriarte M, Barenes KM, Cassorla FG, Cutler GB Jr. The advantage of measuring stimulated as compared with spontaneous growth hormone levels in the diagnosis of growth hormone deficiency. New Engl J Med 1988; 319: 201-7.

30. Donaldson DL, Pan F, Hollowell JG, Stevenson JL, Gifford RA, Moore WV. Reliability of stimulated and spontaneous $\mathrm{GH}$ levels for identifying the child with low GH secretion. J Clin Endocrinol Metab 1991; 72: 647-52.

31. Zadik Z, Chalew SA, Kowarski AA. Reproducibility of growth hormone testing procedures: Quantitative comparison between 24-hour integrated concentration and pharmacological stimulation. J Clin Endocrinol Metab 1990; 71: 1127-30.

32. Hasegawa Y, Hasegawa T, Kotoh S, Tsuchiya Y. Reproducibility of $\mathrm{GH}$ stimulation tests (arginine and insulin), IGF- I and IGFBP-3. Clin Pediatr Endocrinol 1993 (in press).

33. Tsuzaki S, Matsuo N, Osano M. The physical growth of Japanese children from birth to 18 years of age: Cross-sectional percentile growth curve for height and weight. Helv Paediatr Acta 1987; 42: 111-9. 